\title{
Synchronous primary lung cancers in a 51-year-old woman - a case report and literature review
}

\author{
Paweł Rogoziński ${ }^{1}$, Marek Kucharzewski ${ }^{2}$ Krzysztof Bruliński ${ }^{1}$ \\ ${ }^{1}$ Pulmonology and Thoracic Surgery Center in Bystra, Thoracic Surgery Department \\ ${ }^{2}$ Chair and Institute of Descriptive and Topographic Anatomy, Medical University of Silesia
}

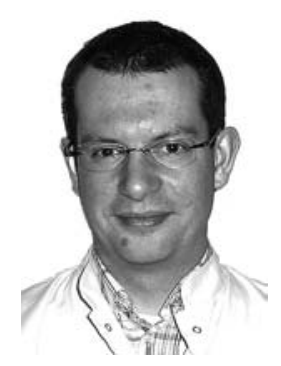

Kardiochirurgia i Torakochirurgia Polska 2013; 10 (4): 410-418

\begin{abstract}
Synchronous primary lung cancers are two primary lung cancers diagnosed at the same time in one patient. The authors report the case of a 51-year-old woman who incidentally discovered tumors in both lungs. The patient underwent cytological diagnosis and PET-CT. There was no radiological evidence of lymph node involvement. On the left side, segmentectomy I was performed (large cell carcinoma), on the right side, upper lobectomy was performed (two foci of adenocarcinoma), and lymphadenectomy was performed on both sides - there was no histopathological evidence of mediastinal lymph node involvement. In view of the obtained results, the patient was diagnosed with synchronous primary lung cancers.

Subsequently, the authors conducted a systematic review of the literature on synchronous primary lung cancers published in the last decade. They point out that the classification of synchronous primary lung cancers still remains an open issue, as it is not taken into consideration by the current TNM classification ( $7^{\text {th }}$ edition).

Key words: synchronous multiple primary lung cancer.
\end{abstract}

\section{Introduction}

The simultaneous presence of two different lung cancers in the same patient was first recorded in a report by Beyreuther in 1924 [1]. Currently, synchronous multiple primary lung cancers (SMPLCS) are diagnosed with varying frequency, and the percentage of noted cases ranges from $0.2 \%$ to $20 \%$ [2]. This disparity results from the difficulties posed by evaluating and differentiating between synchronous cancers and primary cancers with intrapulmonary metastatic changes or metastatic changes in the lungs originating from primary cancers of various organs. SMPLC

\section{Streszczenie}

Synchroniczne pierwotne raki płuc to sytuacja kliniczna, w której rozpoznaje się dwa pierwotne raki płuca w tym samym czasie u jednego chorego. Autorzy opisują przypadek 51-letniej kobiety, u której przypadkowo wykryto guzy w obu płucach. U chorej przeprowadzono diagnostykę cytologiczną oraz wykonano badanie PET-TK. Nie stwierdzono radiologicznych cech zajęcia węzłów chłonnych. W odstępie pięciu tygodni wykonano dwie torakotomie - po stronie lewej wykonano resekcję segmentu szczytowego, uzyskując rozpoznanie raka wielkokomórkowego, a po stronie prawej lobektomię górną, usuwając dwa ogniska raka gruczołowego. Obustronnie zabiegi zostały uzupełnione o limfadenektomię śródpiersia - histopatologicznie nie stwierdzono zajęcia węzłów chłonnych tego regionu. Wobec uzyskanych wyników rozpoznano u chorej synchroniczne pierwotne raki płuc.

W dalszej części autorzy dokonali systematycznego przeglądu piśmiennictwa opublikowanego w ostatnim dziesięcioleciu, dotyczącego synchronicznych pierwotnych raków płuca. Zwracają uwagę, że nadal otwarte pozostaje zagadnienie klasyfikacji synchronicznych pierwotnych raków płuca, która nie jest uwzględniona w obowiązującej klasyfikacji TNM (7 edycja).

Słowa kluczowe: synchroniczny pierwotny rak płuca.

is diagnosed relatively rarely, because such a diagnosis requires meeting certain clearly defined criteria.

In 1975, Martini and Melamed [3] proposed a set of diagnostic criteria designed to facilitate the diagnosis of SMPLC:

I. Clearly separated tumors

II. Histological type:

1) different

2) identical, but in another segment, lobe, or lung, if:

a) it originates from in situ cancer

b) there is no metastasis in the lymph nodes

Address for correspondence: Paweł Rogoziński, Pulmonology and Thoracic Surgery Center in Bystra, Thoracic Surgery Department, ul. J. Fałata 2, 43-360 Bystra, phone: +48 691400 518, fax: +48 3381435 86, e-mail: progozinski81@gmail.com 
c) there is no extrapulmonary metastasis at the time of diagnosis

In turn, in 1995, Antakli et al. [4] added DNA ploidy diagnostics to the criteria regarding histologically identical cancers and proposed the following criteria for the diagnosis of SMPLC:

I. Different histological type

II. Identical histological type and at least two of the following traits:

1) anatomically separated

2) originating from preneoplastic changes

3) no distant metastasis

4) no metastasis to mediastinal lymph nodes

5) different DNA ploidy

Currently, the problem of synchronous lung cancers is encountered more often than in the past due to significant improvements in the area of diagnostic imaging (CT, PET-CT); as a result, more numerous pulmonary lesions are revealed more frequently. The proposed criteria are not always sufficient because of the difficulties in determining the etiology of a malignant lung neoplasm; molecular and genetic diagnostics are indispensable in situations in which the lung tumors have the same histological type [5].

\section{Case study}

A female patient, aged 51, was admitted to the Thoracic Surgery Department in September 2012 for the purpose of diagnosing and treating tumorous growths located in both her lungs. The tumors were revealed by chance on a chest X-ray (Fig. 1) performed in May 2012 on the request of the patient, who was quitting smoking at the time. During

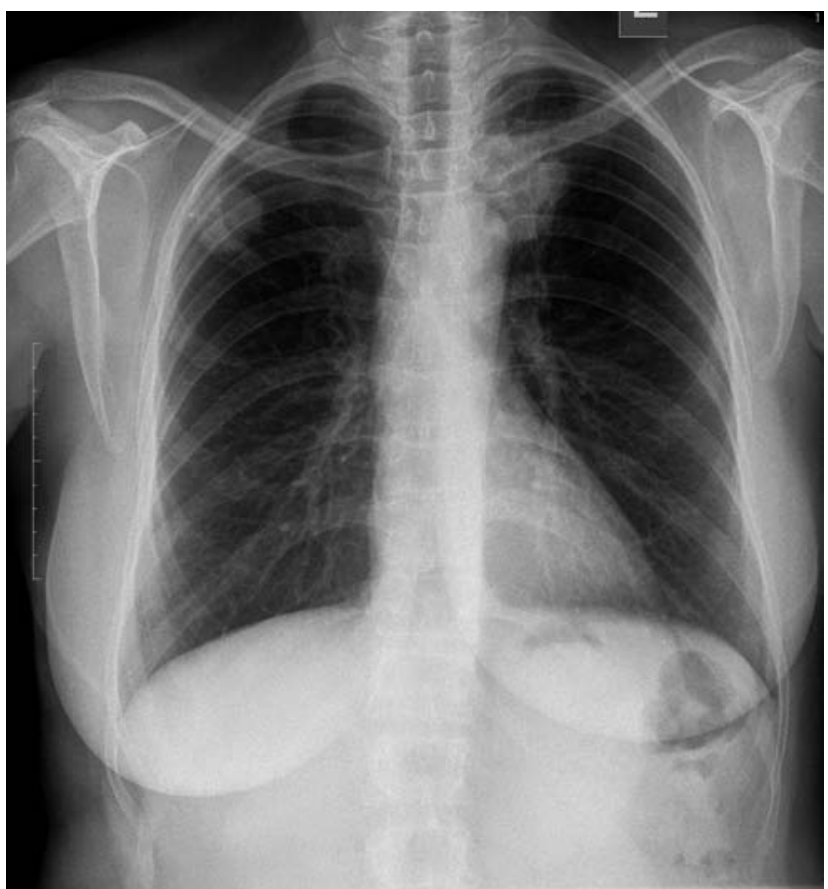

Fig. 1. X-ray of the chest (PA projection). A round shadow in the upper field of the right lung and a round shadow in the upper field of the left lung that time, the patient did not raise any complaints and was not treated due to other pathologies; in 2005, she underwent hysterectomy due to the presence of myomas. The patient had smoked approximately 20 pack-years. She was at risk due to family history, as her father died of diffuse neoplastic disease, and her mother suffered from leukemia.

After a month, a CT scan of the patient's chest was performed, which revealed a tumorous lesion in segment $1 / 2$ of the left lung, $22 \times 27 \mathrm{~mm}$ in size (Fig. 2), as well as a lesion in segment 2 of the right lung, $24 \times 20 \mathrm{~mm}$ in size (Fig. 3) - both underwent contrast enhancement; the CT examination found no lesions in the remaining organs of the chest and epigastrium. The pulmonary diagnostics included a bronchofiberoscopic examination, which did not reveal any endobronchial changes, and a cytological examination of the bronchial aspirate, whose results were negative. The results of additional tests, including spirometry (FEV 2.51 107\%; FEV $\%$ VC 94\%) and arterialized capillary blood gasometry ( $\mathrm{pH}$ 7.498; $\mathrm{pO}_{2} 64.9 \mathrm{~mm} \mathrm{Hg}$; $\mathrm{pCO}_{2}$ $35.6 \mathrm{~mm} \mathrm{Hg} ; \mathrm{O}_{2}$ sat $94.4 \%$ ) were within normal ranges. During this period, a tumor biopsy was attempted; however,

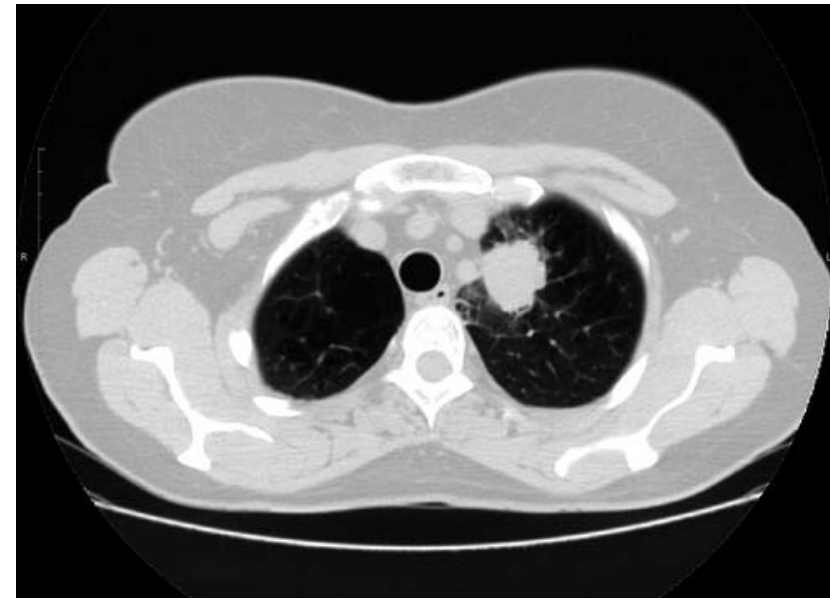

Fig. 2. CT of the chest (axial view). A tumorous change in segment $1 / 2$ of the left lung (size: $22 \times 27 \mathrm{~mm}$ )

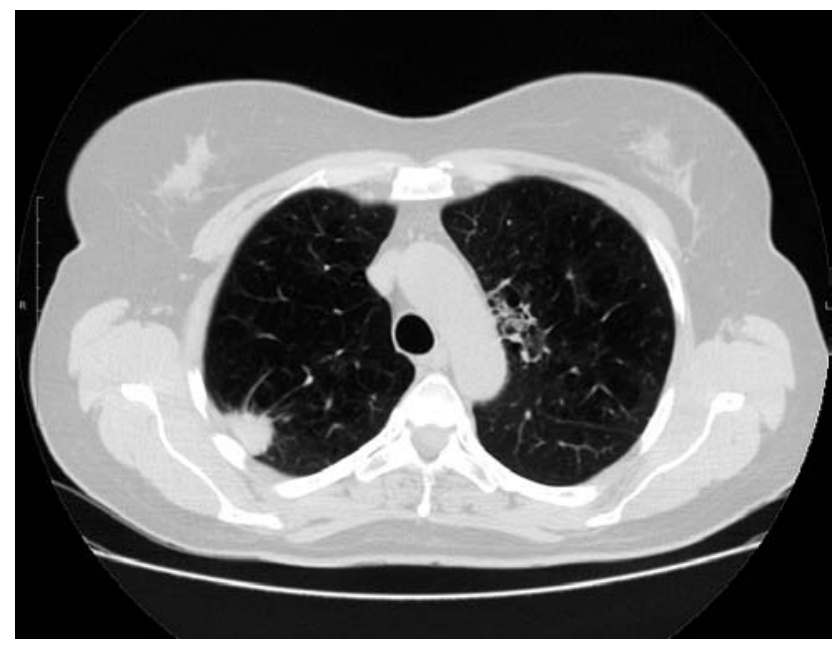

Fig. 3. CT of the chest (axial view). A tumorous lesion in segment 2 of the right lung (size $24 \times 20 \mathrm{~mm}$ ) 
the attempt was aborted due to the proximity of emphysematous changes.

After three months, another tomographic examination of the chest revealed the progression of the lesions in both the left $(36 \times 47 \mathrm{~mm})$ and the right lung $(25 \times 26 \mathrm{~mm})$; furthermore, a satellite nodule $(10 \times 11 \mathrm{~mm}$ in size $)$ appeared in the right superior lobe (Fig. 4). Additional ailments appeared in the form of wandering pains on the right side of

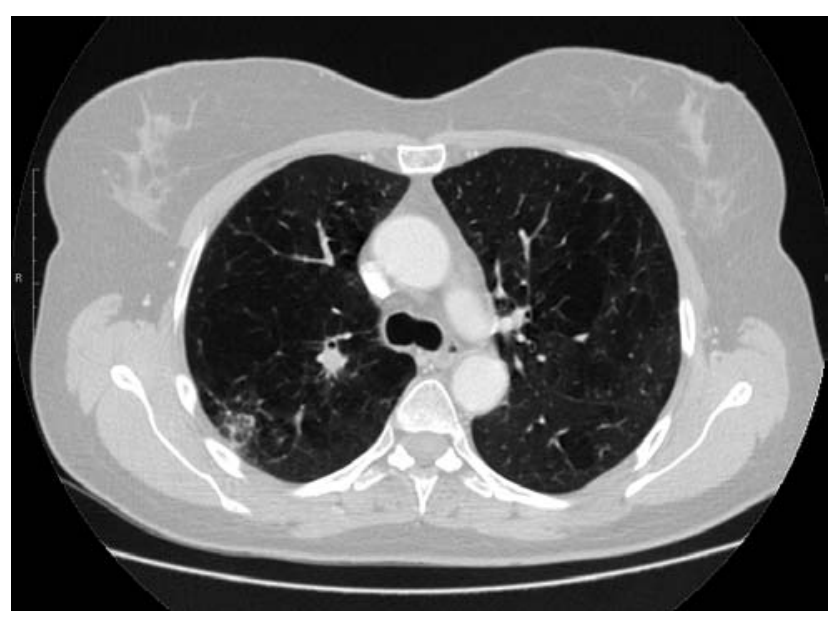

Fig. 4. CT of the chest (axial view). A satellite nodule in the superior lobe of the right lung (size: $10 \times 11 \mathrm{~mm}$ )

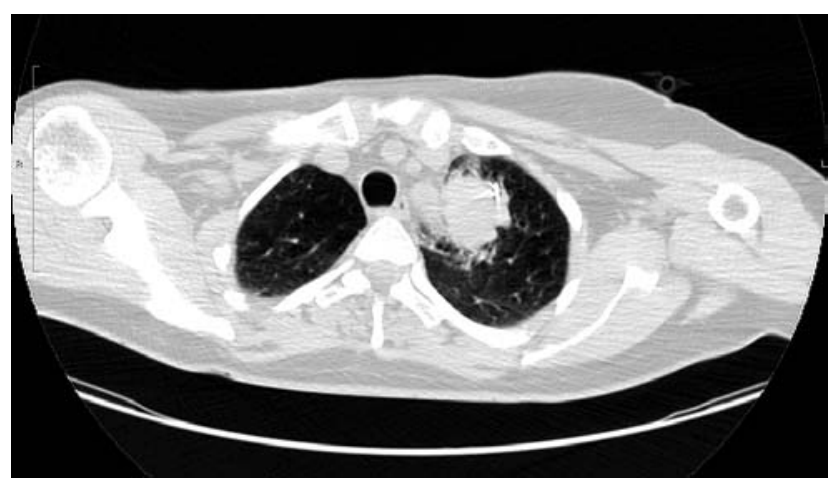

Fig. 5. CT of the chest (axial view). Fine-needle aspiration biopsy of the left lung tumor - the tip of the needle is in the tumor mass

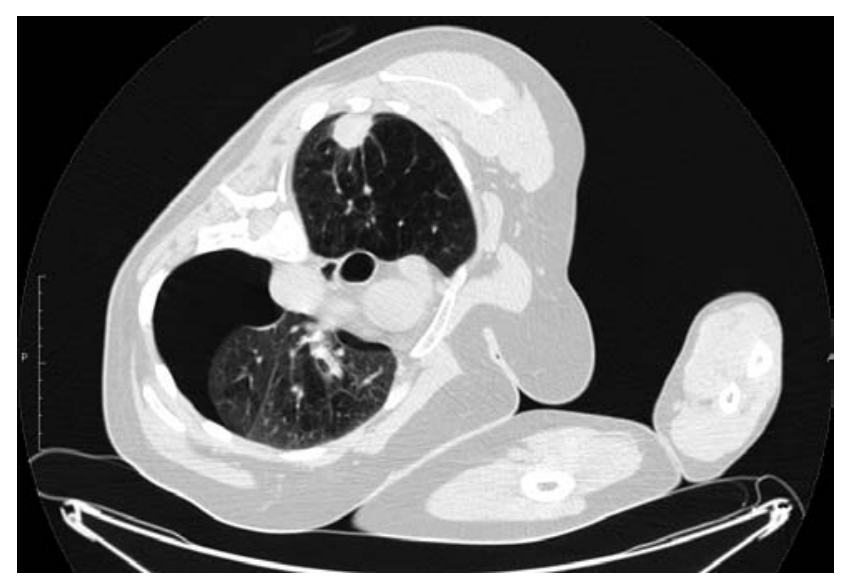

Fig. 6. CT of the chest (axial view). Tumor in the right lung, pneumothorax on the left side the chest and in the neck area accompanied by cough with purulent sputum expectoration.

The patient was qualified for invasive diagnostics in the form of fine-needle aspiration biopsy (FNAB) of the lung tumors. FNAB was first performed on the tumor in the left lung because of its faster progression (one of its dimensions had increased by $20 \mathrm{~mm}$ ). The examination was performed under CT control (Fig. 5), and its course was uneventful. Cytological diagnosis was obtained - non-smallcell lung carcinoma. On the next day, FNAB of the right lung tumor was attempted; however, iatrogenic pneumothorax was revealed on the left side (Fig. 6), and the biopsy was aborted. Lasting lung expansion was achieved after inserting a chest drain into the left pleural cavity.

In October, a PET-CT examination was performed; it revealed active metabolic tumorous changes in segment $1 / 2$ of the left lung (size: $38 \times 42 \mathrm{~mm}$, SUVmax: 37.6) (Fig. 7) and in segment 2 of the right lung, located peripherally (size: $24 \times$ $24 \mathrm{~mm}$, SUVmax: 24.2) and below, more centrally (size: $10 \times$ $11 \mathrm{~mm}$, SUVmax: 17.7) (Fig. 8).

Based on the above imaging results, the lack of signs of mediastinal lymph node involvement, the potential operability of the lesions, the lack of contraindications for lung parenchyma resection, and the long-term outcomes of

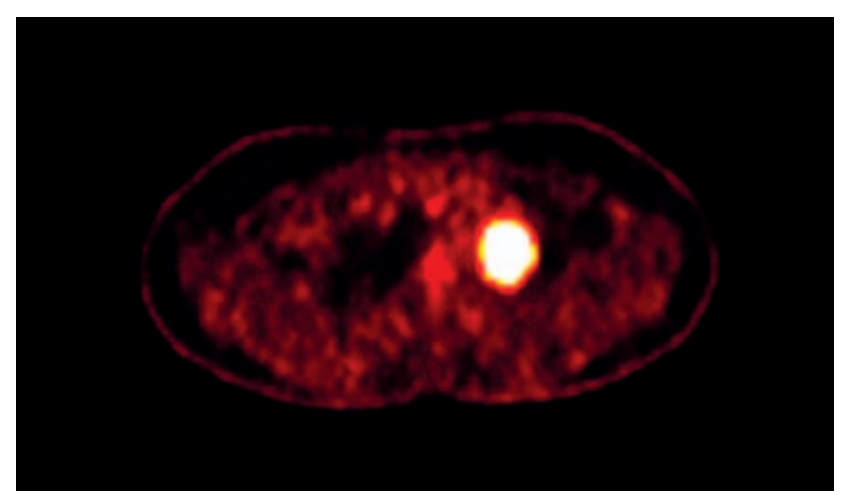

Fig. 7. PET-CT of the chest (axial view). Active metabolic tumorous changes in segment 1/2 of the left lung (size: $38 \times 42 \mathrm{~mm}$, SUVmax: 37.6)

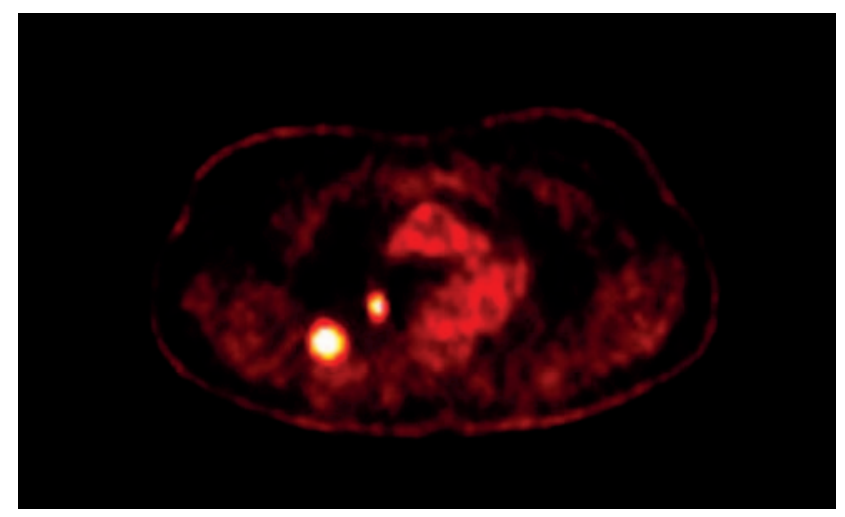

Fig. 8. PET-CT of the chest (axial view). Active metabolic tumorous changes in segment 2 of the right lung: peripheral (size: $24 \times 24$ mm, SUVmax: 24.2) and inferior, more central (size: $10 \times 11 \mathrm{~mm}$, SUVmax: 17.7) 
surgical treatment of diagnosed synchronous cancers [2], the patient was qualified for a surgical procedure.

Before the end of October, an apical segment resection with lymphadenectomy was performed, enabling the achievement of a histopathological diagnosis: large-cell non-neuroendocrine carcinoma (stage: T2bN0). The procedure was complicated by the suppuration of the postoperative wound, which ultimately healed. Five weeks after the first procedure, a right upper lobectomy with lymphadenectomy was performed; histopathologically, the peripheral tumor turned out to be a G1 adenocarcinoma, while the satellite tumor was a G2 adenocarcinoma, resulting in a T3NO stage, with the assumption that the satellite tumor was a metastatic lesion. The postoperative course was uneventful.

Both samples were verified histopathologically - the pathologist confirmed the initial diagnoses. After oncological consultation, the patient was not qualified for systemic treatment; the consulting oncologist recommended observation. Three months after the surgical treatment, a control $\mathrm{CT}$ of the chest and abdominal cavity was performed; it did not reveal any suspicious changes. The patient remains in good clinical condition; the pain and cough have subsided, and the patient does not require analgesic treatment due to the bilateral thoracotomies.

\section{Discussion}

The diagnosis of SMPLCs fits the discussed case study in accordance with both the criteria formulated by Martini and Melamed [3] and the criteria proposed by Antakli et al. [4]. The diagnosed histological types (large cell carcinoma and adenocarcinoma) indicate that the two neoplasms developed independently during the same time period. The microscopic image of the two tumors excludes their affinity, as one of the conditions for the diagnosis of large cell carcinoma is the lack of glandular differentiation [6].

Some uncertainty remains, however, with regard to the satellite tumor, as the two neoplasms in the right lung were both adenocarcinomas (with different levels of differentiation: G1 and G2). According to the aforementioned criteria, the presence of synchronous cancers in the right lung alone may be excluded (the same histological type, but both were located in segment 2). Similarly, Detterbeck et al. [7] argue that such cases should rather be diagnosed as metastatic changes, as corroborated by the longer survival times of patients.

The current $7^{\text {th }}$ edition of the international TNM Classification, developed in cooperation with the International Association for the Study of Lung Cancer (IASLC) [8], does not classify synchronous primary cancers as separate units, but rather suggests treating one of the tumors as a metastasis. Therefore, a second primary lung cancer occurring on the same side but in another lobe should be classified as T4, while the presence of two primary cancers in two lungs is classified as M1a.

Detterbeck et al. [7] suggest that synchronous cancers should be a priori qualified for radical treatment in accordance with the generally accepted rules of treating lung can- cer. Such an approach may be restricted by the respiratory reserve of the patient; however, in the discussed case, the reserve was sufficient for the performance of both procedures.

The four months which passed from revealing the tumors by the X-ray examination to obtaining a diagnosis allowed for the observation of the significant rate of disease progression; the tumor in the left lung increased in size, and a satellite lesion of the right lung tumor appeared. However, no radiological signs of metastasis to the mediastinal lymph nodes were found (as confirmed by the PET-CT examination and ultimately verified by the histopathological results). Based on the above imaging examination results, the authors of this study opted not to conduct mediastinoscopy and mediastinal verification, the results of which constitute important qualification criteria for the surgical treatment of synchronous lung tumors, both uni- and bilateral [5].

Taking into account the interview conducted with the patient, her young age, the lack of contraindications for lung parenchyma resection, and the suggestions found in the available literature [2, 5], oncological consultation was omitted (even though, in the view of the authors, an oncologist may be consulted in non-standard cases), and the patient was qualified for surgical treatment.

The decision to operate first on the tumor located in the left lung was based on its size, rate of expansion, proximity to large vessels, and previous cytological verification (vs. the results of PET-CT for the changes in the right lung) similar criteria were proposed by Ferguson et al. [2]. In turn, Aziz et al. [9] suggest that, in the case of bilateral lesions, if only one tumor was diagnosed, the surgical treatment should first be applied to the non-diagnosed tumor.

The two thoracotomies were performed with an interval of five weeks, which falls within the range reported and suggested by other authors [7].

It is worth noting that the patient's smoking habit confirms the results of previous reports [10] suggesting that tobacco smokers are more susceptible to synchronous lung cancers.

The analysis of the discussed case allows one to conclude that SMPLCs are a nosological entity that can escape the notice of a diagnostician, who, observing multiple tumorous changes in the lungs and having diagnosed one of them as a malignant neoplasm, is prone to suspect metas tasis. The authors underscore the significance of striving for the determination of diagnosis (FNAB) and the extent of the disease (PET-CT), as it offers a chance for successful treatment for patients with sufficient respiratory reserve. Of course, omitting invasive diagnostics of the mediastinum (mediastinoscopy) in spite of negative results of imaging examinations may be debatable; the authors underscore its significance in routine practice [5].

Based on the above case study, the authors performed a systematic review of the available literature. 637 publications were obtained. After limiting the search to studies published within the last ten years, 281 reports remained. The authors rejected studies that pertained to the molecular diagnostics of multiple lung cancers, publications on metachronous lung 
cancers, and studies which reported additional extrapulmonary locations of synchronous malignant neoplasms.

The remaining 38 publications were concerned solely with cases of primary malignant neoplasms occurring within the lungs. The publications were divided into two groups: the first comprised original studies analyzing the practice employed in view of synchronous lung cancer diagnosis and the resulting long-term survival, while the second comprised case reports. In accordance with the assumed criteria, 20 original studies and 18 case reports from the last decade were found pertaining to synchronous lung cancers. Selected studies are presented in Tables I and II.

As mentioned above, SMPLCs are diagnosed relatively rarely. The analyses by individual authors presented in Ta- ble I [5, 10-28] were based on sets of 3 [19] to 175 [17] case studies gathered over periods of time lasting from 4 [26] to 28 [28] years. The included authors conducted retrospective observations and confronted the employed treatment with the achieved long-term survival rates. Most of these studies $[5,10,13,15-25,27,28]$ describe results achieved using surgery, which was sometimes supplemented with oncological treatment; only a few of them $[11,12,14,26]$ pertain to radiation therapy. The fundamental aim of the above studies was to establish the optimal practice in the described cases, even though Ferguson et al. [2] pointed to promising results achieved by means of surgery as early as 1985 .

Chang et al. [11] presented the long-term survival achieved in patients diagnosed with early-stage multiple

Table I. Summary of original works pertaining to synchronous lung cancer published in the years 2003-2013

\begin{tabular}{|c|c|c|c|}
\hline Authors & $\begin{array}{c}\text { Number of patients with synchronous } \\
\text { multiple lung cancer }\end{array}$ & $\begin{array}{l}\text { Treatment (number } \\
\text { of patients) }\end{array}$ & Overall survival \\
\hline Chang et al. [11] & 101 (inoperable) & SABR & $\begin{array}{l}\text { 2-year OS 61.5\% } \\
\text { 4-year OS 39.7\% }\end{array}$ \\
\hline Griffioen et al. [12] & 62 & $\begin{array}{c}\text { SABR (56) } \\
\text { SABR and surgery (6) }\end{array}$ & 2-year OS 56\% \\
\hline Xue et al. [10] & $10(2000-2010)$ & $\begin{array}{c}\text { Surgery (3) } \\
\text { Surgery + ChT/RT (4) } \\
\text { Chemoradiation (3) }\end{array}$ & $\begin{array}{l}\text { 2-year OS 66\% } \\
\text { 2-year OS 50\% } \\
\text { 2-year OS 0\% }\end{array}$ \\
\hline Shah et al. [13] & 47 (1997-2010) & $\begin{array}{c}\text { Surgery (36) } \\
\text { Surgery + ChT (11) }\end{array}$ & 3-year OS 35\% \\
\hline Creach et al. [14] & 15 (high risk of surgical resection) & SBRT & 2-year OS 27.5\% \\
\hline Jung et al. [15] & $32(1995-2008)$ & Surgery & 5-year OS 60.9\% \\
\hline Fabian et al. [16] & 67 (1996-2009) & Surgery & $\begin{array}{l}\text { 3-year OS 64\% } \\
\text { 5-year OS 53\% }\end{array}$ \\
\hline Kocaturk et al. [5] & $26(2001-2008)$ & Surgery + ChT/RT & 5-year OS 49.7\% \\
\hline Finley et al. [17] & $175(1995-2006)$ & Surgery & 3 -year OS 64\% \\
\hline Voltolini et al. [18] & 43 (1990-2007) & Surgery & $\begin{array}{c}\text { 5-year OS } 34 \% \\
\text { N1,2-0\% } \\
\text { NO }-57 \%\end{array}$ \\
\hline Carretta et al. [19] & $3(1988-2005)$ & Surgery & 5-year OS 66\% \\
\hline De Leyn et al. [20] & 36 (1990-2007) & Surgery & 5-year OS 38\% \\
\hline Rostad et al. [21] & 94 (1993-2000) & Surgery & $\begin{array}{c}\text { 5-year OS } 31.4 \% \text { carcinoma planoepitheliale } \\
\text { 5-year OS } 23.2 \% \text { adenocarcinoma } \\
\text { 5-year OS } 42.7 \% \text { other cancers }\end{array}$ \\
\hline Trousse et al. [22] & $56(1985-2006)$ & Surgery & $\begin{array}{c}5 \text {-year OS } 48.2 \% \\
10 \text {-year OS } 29.9 \% \\
\end{array}$ \\
\hline Chang et al. [23] & 92 (past 16 years) & Surgery & $\begin{array}{c}\text { 5-year OS 35.3\% } \\
\text { N1,2-15.5\% } \\
\text { NO }-52.5 \%\end{array}$ \\
\hline Trousse et al. [24] & $125(1985-2006)$ & Surgery & $\begin{array}{c}\text { 2-year OS 61.6\% } \\
\text { 5-year OS 34\% }\end{array}$ \\
\hline Mun et al. [25] & 19 (1999-2004) & Surgery & $\begin{array}{l}\text { 3-year OS } 94.7 \% \\
5 \text {-year OS } 75.8 \%\end{array}$ \\
\hline Sinha et al. [26] & 10 (9 inoperable, 1 refused) (2001-2005) & SBRT & All alive in 2006 \\
\hline Feng et al. [27] & 31 (1983-2004) & Surgery & $\begin{array}{l}\text { 1-year OS 52\% } \\
\text { 3-year OS } 29 \% \\
\text { 5-year OS } 20 \%\end{array}$ \\
\hline Tsunezuka et al. [28] & $18(1973-2001)$ & Surgery & $\begin{array}{l}5 \text {-year OS 69\% } \\
10 \text {-year OS } 47 \%\end{array}$ \\
\hline
\end{tabular}

OS - overall survival, SABR - stereotactic ablative radiotherapy, SBRT - stereotactic body radiation therapy, ChT - chemotherapy, $R T$ - radiotherapy, $N$ - nodes 
Table II. Summary of case reports pertaining to synchronous lung cancer published in the years 2003-2013

\begin{tabular}{|c|c|c|c|c|c|c|}
\hline Authors & $\begin{array}{l}\text { Age }(y) \\
\text { sex }\end{array}$ & $\begin{array}{c}\text { Type of cancer (number of } \\
\text { tumors) }\end{array}$ & $\begin{array}{l}\text { Unilateral/ } \\
\text { bilateral }\end{array}$ & Comments & Treatment & Survival \\
\hline Ito et al. [29] & $78, \mathrm{~F}$ & $\begin{array}{c}\text { Carcinoma planoepitheliale (1) } \\
\text { Adenocarcinoma (2) }\end{array}$ & Unilateral & In one lobe & $\begin{array}{c}\text { Lobectomy }+ \\
\text { lymphadenectomy }\end{array}$ & \\
\hline $\begin{array}{l}\text { Nagamatsu et al. } \\
\text { [30] }\end{array}$ & $67, \mathrm{~F}$ & $\begin{array}{l}\text { Adenocarcinoma (1) } \\
\text { Carcinoid (1) }\end{array}$ & Unilateral & $\begin{array}{l}\text { In one tumor } \\
\text { (cancer-in-cancer) }\end{array}$ & $\begin{array}{c}\text { Lobectomy }+ \\
\text { lymphadenectomy }\end{array}$ & \\
\hline \multirow{2}{*}{ Ohtsuka et al. [31] } & $63, M$ & Adenocarcinoma (2) & Unilateral & In two lobes & \multirow{2}{*}{$\begin{array}{l}\text { Segmentectomy + } \\
\text { lymphadenectomy }\end{array}$} & \\
\hline & $67, M$ & Adenocarcinoma (2) & Unilateral & In two lobes & & \\
\hline $\begin{array}{l}\text { Sepehripour et al. } \\
\text { [32] }\end{array}$ & $70, M$ & $\begin{array}{c}\text { Carcinoma planoepitheliale (1) } \\
\text { Adenocarcinoma (1) }\end{array}$ & Unilateral & In one lobe & $\begin{array}{c}\text { Lobectomy }+ \\
\text { lymphadenectomy }\end{array}$ & \\
\hline Loo et al. [33] & $74, M$ & Carcinoma planoepitheliale (2) & Bilateral & Inoperable & IMRT & $\begin{array}{l}\text { Alive after } \\
48 \text { months }\end{array}$ \\
\hline $\begin{array}{l}\text { Yoshimoto et al. } \\
\text { [34] }\end{array}$ & $52, \mathrm{~F}$ & $\begin{array}{c}\text { Adenocarcinoma (1) } \\
\text { Bronchioloalveolar carcinoma (1) }\end{array}$ & Unilateral & In one lobe & $\begin{array}{l}\text { Lobectomy }+ \\
\text { lymphadenectomy }\end{array}$ & \\
\hline Okita et al. [35] & $71, \mathrm{~F}$ & Carcinoma planoepitheliale (3) & Unilateral & In one lobe & Lobectomy & \\
\hline Yazici et al. [36] & $58, \mathrm{~F}$ & Typical carcinoid (2) & Bilateral & & $\begin{array}{l}\text { Wedge resection }+ \\
\text { lymphadenectomy }\end{array}$ & \\
\hline Matsuoka et al. [37] & $79, \mathrm{~F}$ & Adenocarcinoma (2) & Bilateral & & $\begin{array}{l}\text { Lobectomy + } \\
\text { segmentectomy }\end{array}$ & \\
\hline Hosaka et al. [38] & $65, F$ & Adenocarcinoma (2) & Bilateral & & $\begin{array}{c}\text { Lobectomy }+ \\
\text { segmentectomy }+ \\
\text { lymphadenectomy via } \\
\text { sternotomy }\end{array}$ & \\
\hline Camargo et al. [39] & $62, \mathrm{~F}$ & Carcinoid (3) & Bilateral & & Sublobar resections & \\
\hline Froio et al. [40] & $59, M$ & $\begin{array}{l}\text { Adenocarcinoma (1) } \\
\text { Carcinoma planoepitheliale (1) } \\
\text { Carcinoma microcellulare (1) }\end{array}$ & Unilateral & & $\begin{array}{l}\text { Lobectomy + } \\
\text { segmentectomy }\end{array}$ & \\
\hline Damas et al. [41] & $50, F$ & $\begin{array}{c}\text { Carcinoma microcellulare (1) } \\
\text { Adenocarcinoma (1) }\end{array}$ & Bilateral & $\begin{array}{c}\text { Hepatic } \\
\text { metastasis }\end{array}$ & $\mathrm{ChT}+\mathrm{RT}$ & $\begin{array}{l}\text { Alive after } \\
28 \text { months }\end{array}$ \\
\hline Ryoo et al. [42] & $66, M$ & $\begin{array}{l}\text { Bronchioloalveolar carcinoma (2) } \\
\text { Carcinoma planoepitheliale (1) }\end{array}$ & Bilateral & & ChT & \\
\hline Kobashi et al. [43] & $73, M$ & $\begin{array}{c}\text { Carcinoma microcellulare (1) } \\
\text { Adenocarcinoma (1) }\end{array}$ & Unilateral & In one lobe & $\begin{array}{l}\text { ChT + lobectomy + } \\
\text { lymphadenectomy }\end{array}$ & \\
\hline Khan et al. [44] & $75, M$ & $\begin{array}{l}\text { Carcinoma non-microcellulare } \\
\text { (2) }\end{array}$ & Unilateral & & $\begin{array}{l}\text { Wedge resection + } \\
\text { segmentectomy }\end{array}$ & $\begin{array}{c}\text { Alive after } \\
6 \text { months, } \\
\text { relapse }\end{array}$ \\
\hline Fujiwara et al. [45] & $40, \mathrm{~F}$ & $\begin{array}{c}\text { Carcinoma non-microcellulare } \\
\text { (2) }\end{array}$ & Bilateral & & $\begin{array}{c}\text { Lobectomy + } \\
\text { segmentectomy }\end{array}$ & \\
\hline Mizuguchi et al. [46] & $51, M$ & $\begin{array}{l}\text { Large cell carcinoma (1) } \\
\text { Adenocarcinoma (1) }\end{array}$ & Bilateral & $\begin{array}{l}\text { Cancer in } \\
\text { the walls of } \\
\text { bullae }\end{array}$ & Lobectomy + bullectomy & $\begin{array}{l}\text { Alive after } \\
3 \text { years }\end{array}$ \\
\hline
\end{tabular}

F-female, M-male, IMRT - intensity-modulated radiotherapy, ChT-chemotherapy, RT-radiotherapy

synchronous lung cancers, in whom there were contraindications for pulmonary parenchyma resection. Stereotactic ablative radiotherapy (SABR) was used in these patients; the achieved 2-year overall survival rate was $61.5 \%$. Similarly, Griffioen et al. [12] promote this type of treatment in selected patients (no signs of lymph node involvement). The method's 2-year survival rate may be as high as 56\%; the authors also point to its low toxicity and good local control after irradiation. Creach et al. [14] and Sinha et al. [26] conclude that using stereotactic body radiation therapy (SBRT) is a safe and efficacious method for patients in whom surgery is burdened with high risk and in patients not consenting to surgical procedures. They also observed that both progression-free survival (PFS) and overall surviv- al (OS) are better in the case of metachronous tumors than in the case of synchronous tumors [11, 14], and that local control of lesions after irradiation is beneficial in the case of synchronous tumors.

It is worth highlighting that topical treatment using only ionizing radiation is an efficacious low-risk method, which may be offered to patients who do not qualify for surgical intervention due to medical reasons or lack of consent [26]. Provided that the patients are properly qualified (no lymph node metastasis), the achieved long-term survival rates are comparable to those achieved after surgical intervention.

Xue et al. [10] present 10 case studies with different treatment regimens. All of the operated patients were negative for lymph node involvement. The best survival 
rates were achieved in patients operated on for T1a and T1b tumors, in whom lobectomies and segmentectomies were performed. Patients in whom pneumonectomy was performed and supplemented with chemoradiotherapy (T1a-T3 tumors) had worse 2-year survival rates; the results were the worst among patients treated only with chemoradiotherapy (T2a tumors, one person with $\mathrm{N} 1$ lymph node involvement).

Kocaturk et al. [5] analyzed 26 patients operated on due to synchronous lung cancers, who received postoperative oncological treatment. Based on the obtained results, the authors concluded that surgical treatment is a low-risk option which offers a chance for a long survival. They suggest avoiding pneumonectomy in favor of lobectomy and segmentectomy, as the 5 -year survival rate after lung removal was $27 \%$, while after the other resections it was $71.1 \%$. Long-term survival rates after resections less extensive than pneumonectomy did not differ between each other; therefore, the authors recommend performing resections which guarantee complete tumor removal, preferring segmentectomy in patients with low respiratory reserves. Like Trousse et al. [24], they also noted that postoperative chemotherapy may be of benefit to the patient's future health status.

Shah et al. [13] recommend aggressive surgery in patients with bilateral synchronous lung cancers. Most of the operated patients underwent pulmonary parenchyma resections (wedge resections, segmentectomies, lobectomies) using a videothoracoscopic approach (96\% lateral, $60 \%$ bilateral); in over $23 \%$ of them, adjuvant therapy was required. The 3-year overall survival rate was 35\%. Feng et al. [27] also recommend aggressive surgical treatment; however, their results were less promising, as the 3-year survival rate was $29 \%$. This may be a result of performing pneumonectomies in the study group. Tsunezuka et al. [28] advise employing aggressive surgical treatment as well; they report conducting parenchymal sparing procedures (sleeve resections), which directly influenced the long-term treatment outcomes (5-year survival was 69\%).

Jung et al. [15] reported that female gender [17], younger age, not smoking, $\mathrm{FEV}_{1} / \mathrm{FVC} \geq 70 \%$, small tumor size (pT1), and identical histological pattern of cancer tissue were associated with longer survival; PFS was influenced by tumor size and lymph node status (pT1N0), as well as by identical histological pattern. De Leyn et al. [20] did not find any significant differences in terms of long-term survival between patients with different histopathological types and patients with the same histopathological type of cancer. Trousse et al. [24] demonstrated that conducting pneumonectomies significantly deteriorates long-term survival.

Fabian et al. [16] highlight the survival rates achieved after the treatment of bilateral synchronous lung cancers with identical histological pattern (with the exception of bronchioloalveolar carcinoma) and negative N2 parameter. According to the current TNM classification, such patients should be considered as stage IV (Ma1 parameter), but the 5-year survival rates achieved by the authors of the said report, reaching 53\%, are incongruent with survival rates estimated for such an advanced stage of lung cancer [20, 22]. Additionally, Finley et al. [17] state that 5-year survival estimated for patients with SMPLCs is comparable to the survival of patients with single cancers in the same stages of advancement.

Voltolini et al. [18] clearly demonstrated that lymph node metastasis concomitant with two non-small-cell cancers in the lungs does not offer any chance for long-term survival (5-year survival: 0\%); however, excluding lymph node metastasis [20] using a PET-CT examination and/or mediastinoscopy allows for the selection of patients with negative $\mathrm{N}$ parameters who may undergo efficacious surgical treatment (5-year survival: 57\%). Chang et al. [23] achieved the following 5-year survival rates depending on lymph node status: $15.5 \%$ (metastasis present) and 52.5\% (negative $\mathrm{N}$ parameter).

The analysis of synchronous lung adenocarcinomas by Carretta et al. [19] confirmed the validity of performing sublobar resections; the authors argued that the said procedures provide sufficient oncological radicality and offer a chance for long-term survival (5-year survival: 66\%). Worse outcomes were reported by Rostad et al. [21], who evaluated 5-year survival in dependence on the histopathological diagnosis of concomitant primary cancers with identical pattern. In the case of adenocarcinoma, the 5 -year survival rate was $23.2 \%$, and in the case of squamous carcinoma it was $31.4 \%$.

Mun et al. [25] presented the long-term outcomes of concurrent surgical treatments for synchronous cancers conducted in 19 patients (15 stage IA patients). In 14 patients, lung parenchyma resections were performed using a sternotomy approach, and in 5 patients via VATS (videoassisted thoracic surgery). Thirteen patients underwent lobectomy and wedge resection on the opposite side; bilateral wedge resection was performed in 5 patients, and one patient underwent segmentectomy and wedge resection. Adenocarcinomatous pattern was revealed in 84 of the removed lesions; the remaining lesions were identified as squamous carcinoma. The authors reported 5 -year survival at the level of $75.8 \%$, which correlates with the early stages of advancement of the patients qualified for surgery.

Within the last 10 years, 18 case reports have been published (Table II) [29-46]. Their authors described a total of 19 cases of SMPLCs: 10 of them in women and 9 in men. The mean age of the operated patients was 64.4 years, and the mean age of the patients undergoing oncological treatment was 63 years [33, 41, 42].

The most frequently diagnosed neoplasms included lung adenocarcinoma (12 cases), followed by squamous carcinoma (6 cases), small cell carcinoma and carcinoid tumors (3 cases each). Bronchioloalveolar carcinoma and non-smallcell carcinoma were diagnosed in two patients each, and large-cell carcinoma was found in one patient. In 10 patients, the tumors were located in one lung only, while in the remaining cases both lungs were involved. The most frequently conducted surgical procedure was lobectomy (11 patients); sublobar resections, i.e. segmentectomy and wedge 
resection, were performed in 6 and 3 patients, respectively. Eight patients underwent mediastinal lymph node excision.

Oncological therapy was employed in three cases [33, 41, 42]. In one case, the tumors were inoperable (two synchronous squamous carcinoma tumors located in both lungs) [33] - the patient underwent intensity-modulated radiotherapy (IMRT) and was alive after 4 years. Another patient was diagnosed with adenocarcinoma in one lung and smallcell carcinoma in the other; metastases to the liver were also present [41]. Oncological combination therapy was employed (chemotherapy + radiation therapy), and the patient survived for over 2 years.

Nagamatsu et al. [30] describe the case of a 67-year-old woman, in whom non-small-cell carcinoma was diagnosed intraoperatively. The patient underwent lobectomy and lymphadenectomy. Postoperative slide examination revealed that within the main adenocarcinomatous tumor, there was a scar, in which a carcinoid developed (cancer-in-cancer). Hosaka et al. [38] present the case of a 65-year-old patient diagnosed with bilateral synchronous lung tumors. Intraoperatively, two adenocarcinomatous tumors were identified, and both lesions were excised concurrently via sternotomy. A right upper lobectomy and a left segmentectomy with lymphadenectomy were performed. The postoperative course was successful.

Finally, Mizuguchi et al. [46] analyzed the case of a 51-yearold man treated with lobectomy and bullectomy due to bilateral emphysematous bullae. Histopathological examination revealed the presence of large-cell carcinoma in the wall of one of the bullae as well as adenocarcinoma in the wall of another emphysematous bulla. No signs of recurrence were observed three years after the operation.

One of the conclusions drawn from this review of studies concerning synchronous multiple primary lung cancers published within the last ten years is that the status of this nosological entity is not yet fully determined, as it does not fit well into the current TNM classification of lung cancer ( $7^{\text {th }}$ edition). The authors of the listed studies $[5,13$, $15-20,23-25,27,28]$ argue that surgery is an efficacious treatment for this disease and should be considered if no contraindications are present. They also demonstrated that, in spite of conducting sublobar resections, the prognosis for patients with at least two primary lung cancers with no lymph node involvement is comparable to the outcomes achieved in patients with similarly staged single lesions. Although the incidence of SMPLCs is very low, which may result from underdiagnosis and treating patients with multiple lung lesions as potential candidates for systemic treatment, the described treatment options should always be taken into consideration, because well-planned surgical treatment may offer a chance for long-term survival.

\section{References}

1. Beyreuther H. Multipicate von carcinomen bei einem fall von sog. Schenecberger Lungenkrebs mit tuberkulose. Virchows Arch 1924; 250: 230-243.

2. Ferguson MK, DeMeester TR, DesLauriers J, Little AG, Piraux M, Golomb H. Diagnosis and management of synchronous lung cancers. J Thorac Cardiovasc Surg 1985; 89: 378-385
3. Martini N, Melamed MR. Multiple primary lung cancers. J Thorac Cardiovasc Surg 1975; 70: 606-612.

4. Antakli T, Schaefer RF, Rutherford JE, Read RC. Second primary lung cancer. Ann Thorac Surg 1995; 59: 863-867.

5. Kocaturk Cl, Gunluoglu MZ, Cansever L, Demir A, Cinar U, Dincer SI, Bedirhan MA. Survival and prognostic factors in surgically resected synchronous multiple primary lung cancers. Eur J Cardiothorac Surg 2011; 39: 160-166.

6. Langfort R. Klasyfikacja histopatologiczna raka płuca. Pol J Pathol 2010; 1 (Suplement 1): s24-s33.

7. Detterbeck FC, Jones DR, Kernstine KH, Naunheim KS. Lung cancer. Special treatment issues. Chest 2003; 123 (1 Suppl): 244S-258S.

8. Detterbeck FC, Boffa DJ, Tanoue LT. The new lung cancer staging system. Chest 2009; 136: 260-271.

9. Aziz TM, Rasheed AS, Glasser J, Jilaihawi AV, Prakash D. The management of second primary lung cancers. A single centre experience in 15 years. Eur J Cardiothorac Surg 2002; 21: 527-533.

10. Xue X, Xue Q, Wang N, Zhang L, Guo L, Li X, Sun J, Wang J. Early clinical diagnosis of synchronous multiple primary lung cancer. Oncol Lett 2012; 3: 234-237.

11. Chang JY, Liu YH, Zhu Z, Welsh JW, Gomez DR, Komaki R, Roth JA, Swisher SG. Stereotactic ablative radiotherapy: A potentially curable approach to early stage multiple primary lung cancer. Cancer 2013; 119: 3402-3410.

12. Griffioen GH, Lagerwaard FJ, Haasbeek CJ, Smit EF, Slotman BJ, Senan S. Treatment of multiple primary lung cancers using stereotactic radiotherapy, either with or without surgery. Radiother Oncol 2013; 107: 403-408.

13. Shah AA, Barfield ME, Kelsey CR, Onaitis MW, Tong B, Harpole D, D'Amico TA, Berry MF. Outcomes after surgical management of synchronous bilateral primary lung cancers. Ann Thorac Surg 2012; 93: 1055-1060.

14. Creach KM, Bradley JD, Mahasittiwat P, Robinson CG. Stereotactic body radiation therapy in the treatment of multiple primary lung cancers. Radiother Oncol 2012; 104: 19-22.

15. Jung EJ, Lee JH, Jeon K, Koh WJ, Suh GY, Chung MP, Kim H, Kwon OJ, Shim YM, Um SW. Treatment outcomes for patients with synchronous multiple primary non-small cell lung cancer. Lung Cancer 2011; 73: 237-242.

16. Fabian T, Bryant AS, Mouhlas AL, Federico JA, Cerfolio RJ. Survival after resection of synchronous non-small cell lung cancer. J Thorac Cardiovasc Surg 2011; 142: 547-553.

17. Finley DJ, Yoshizawa A, Travis W, Zhou Q, Seshan VE, Bains MS, Flores RM, Rizk N, Rusch VW, Park BJ. Predictors of outcomes after surgical treatment of synchronous primary lung cancers. J Thorac Oncol 2010; 5: 197-205.

18. Voltolini L, Rapicetta C, Luzzi L, Ghiribelli C, Paladini P, Granato F, Gallazzi M, Gotti G. Surgical treatment of synchronous multiple lung cancer lo cated in a different lobe or lung: high survival in node-negative subgroup. Eur J Cardiothorac Surg 2010; 37: 1198-1204.

19. Carretta A, Ciriaco P, Melloni G, Bandiera A, Libretti L, Puglisi A, Giovanardi $M$, Zannini P. Surgical treatment of multiple primary adenocarcinomas of the lung. Thorac Cardiovasc Surg 2009; 57: 30-34.

20. De Leyn P, Moons J, Vansteenkiste J, Verbeken E, Van Raemdonck D, Nafteux $\mathrm{P}$, Decaluwe $\mathrm{H}$, Lerut T. Survival after resection of synchronous bilateral lung cancer. Eur J Cardiothorac Surg 2008; 34: 1215-1222.

21. Rostad H, Strand TE, Naalsund A, Norstein J. Resected synchronous primary malignant lung tumors: a population-based study. Ann Thorac Surg 2008; 85: 204-209.

22. Trousse D, D'Journo XB, Avaro JP, Doddoli C, Giudicelli R, Fuentes PA, Thomas PA. Multifocal T4 non-small cell lung cancer: a subset with improved prognosis. Eur J Cardiothorac Surg 2008; 33: 99-103.

23. Chang YL, Wu CT, Lee YC. Surgical treatment of synchronous multiple primary lung cancers: experience of 92 patients. J Thorac Cardiovasc Surg 2007; 134: 630-637.

24. Trousse D, Barlesi F, Loundou A, Tasei AM, Doddoli C, Giudicelli R, Astoul P, Fuentes $P$, Thomas P. Synchronous multiple primary lung cancer: an increasing clinical occurrence requiring multidisciplinary management. J Thorac Cardiovasc Surg 2007; 133: 1193-1200.

25. Mun M, Kohno T. Single-stage surgical treatment of synchronous bilateral multiple lung cancers. Ann Thorac Surg 2007; 83: 1146-1151.

26. Sinha B, McGarry RC. Stereotactic body radiotherapy for bilateral primary lung cancers: the Indiana University experience. Int J Radiat Oncol Biol Phys 2006; 66: 1120-1124

27. Feng FY, Zhang DC, Liu XY, Wang YG, Mao YS. Surgical treatment and prognosis of synchronous double primary lung cancer: a report of 31 cases. $\mathrm{Ai}$ Zheng 2005; 24: 215-218.

28. Tsunezuka Y, Matsumoto I, Tamura M, Oda M, Ohta Y, Shimizu J, Kawakami K, Watanabe Y, Tanaka Y, Watanabe G, Minato H. The results of therapy 
for bilateral multiple primary lung cancers: 30 years experience in a single centre. Eur J Surg Oncol 2004; 30: 781-785.

29. Ito T, Kawasaki N, Kinoshita M, Inada H, Tei S, Ikeda N. Triple synchronous primary lung carcinomas in the same lobe; report of a case. Kyobu Geka 2012; 65: 832-835.

30. Nagamatsu Y, Iwasaki Y, Omura H, Kumazoe H, Hyashida R, Shirouzu K. A case of resected synchronous multiple primary lung cancer comprising adenocarcinoma and carcinoid (cancer-in-cancer). Gen Thorac Cardiovasc Surg 2012; 60: 518-521.

31. Ohtsuka T, Okui M, Nakayama T, Asakura K, Izumi Y, Horinouchi H, Nomori H. Multiple segmentectomy for synchronous multiple small peripheral lung cancers: report of two cases. Ann Thorac Cardiovasc Surg 2012; 18: 462-464.

32. Sepehripour AH, Nasir A, Shah R. Multiple synchronous primary tumours in a single lobe. Interact Cardiovasc Thorac Surg 2012; 14: 340-341.

33. Loo SW, Smith S, Promnitz DA, Van Tornout F. Synchronous bilateral squamous cell carcinoma of the lung successfully treated using intensity-modulated radiotherapy. Br J Radiol 2012; 85: 77-80.

34. Yoshimoto K, Yoshida J, Ishii G, Nishimura M, Hishida T, Nagai K. Two lung adenocarcinomas in the same lobe: multiple primaries or intrapulmonary metastasis? Ann Thorac Cardiovasc Surg 2011; 17: 584-587.

35. Okita R, Shimizu K, Mimura T, Miyata Y, Okada M, Arihiro K. Suggestive synchronous triple squamous cell carcinoma of the lung in the same lobe. Gen Thorac Cardiovasc Surg 2010; 58: 427-430.

36. Yazici U, Gulhan E, Agackiran Y, Tastepe I, Yaran P. Synchronous bilateral multiple typical pulmonary carcinoid tumors. Ann Thorac Surg 2010; 89: 1278-1280.

37. Matsuoka T, Fukamitsu G, Onoda M, Uesugi N, Kawano K, Katou T. Synchronous multiple lung cancer including a lesion with a thin-walled cavity; report of a case. Kyobu Geka 2010; 63: 164-167.
38. Hosaka Y, Motono N, Satou S, Yoshiya K, Yamato Y, Koike T. Single-stage operation for synchronous bilateral multiple lung cancer through median sternotomy. Kyobu Geka 2009; 62: 456-459.

39. Camargo SM, Machuca TN, Moreira AL, Schio SM, Moreira JS, Camargo JJ. Multiple synchronous bronchial carcinoid tumors: report of a case. Thorac Cardiovasc Surg 2009; 57: 58-60.

40. Froio E, D’Adda T, Fellegara G, Ampollini L, Carbognani P, Rindi G. Three different synchronous primary lung tumours: a case report with extensive genetic analysis and review of the literature. Lung Cancer 2008; 59: 395-402.

41. Damas C, Saleiro S, Hespanhol VP. Bilateral lung masses: the same aetiology? Rev Port Pneumol 2007; 13: 287-291.

42. Ryoo BY, Na II, Yang SH, Koh JS, Kim CH, Lee JC. Synchronous multiple primary lung cancers with different response to gefitinib. Lung Cancer 2006; 53: 245-248.

43. Kobashi Y, Fukuda M, Yoshida K, Miyashita N, Niki Y, Oka M. Synchronus presentation of early-stage small cell carcinoma and adenocarcinoma in the same lung lobe. Intern Med 2006; 45: 287-291.

44. Khan F, Thayer J, Bauer F, Bilgrami S. Synchronous lung cancers: case report and review of the literature. Conn Med 2005; 69: 461-463.

45. Fujiwara K, Nagaoka M, Taniguchi E. Multiple primary lung cancer diagnosed by thoracic computed tomography; report of 2 cases. Kyobu Geka 2004; 57: 334-337.

46. Mizuguchi S, Nishida T, Kawata Y, Izumi N, Nishiyama N, Inoue K. Synchronous double cancers developing from the wall of bullae in the bilateral lungs. Jpn J Thorac Cardiovasc Surg 2004; 52: 36-40. 